\title{
Influence of kids on purchasing decision in Family Study of Households in Jalandhar
}

\author{
Preeti Thakur \\ Assistant Professor, Department of Management Studies, Maharishi Markandeshwar University, Solan (H.P.)
}

\begin{abstract}
The purpose of this paper seeks to find out the Influence of kids on purchasing decision in family. Second purpose is to find the influence of kids in purchasing decision by product category and another purpose is to study the factors which influence children's decision in selecting a product. The findings of this research shows that there is important role of child in purchasing decision of product in family and there is significance relationship between age of child and involvement of child in purchasing decision. I have found the factors which influence decision of children in selecting a products, and four major factors that came out are advertisement enhance the knowledge of children regarding the products, any specific toy or gift attached with the product influence the child to purchase the product, they are influenced by their friends and they get influenced by the packaging of the product.
\end{abstract}

Keywords: Purchasing, advertising, Kids

\section{Introduction:}

Purchasing decision making is a complex and multistage process, which undertaken not only by purchaser himself, but under the impact of other parties as well. Family decision making constitutes an important area to explore. This importance is frequently highlighted by marketing practitioners as well as scholars studying the area.

Although the influence of children in the family decision making process has been accepted as a force which neither academics nor practitioners can ignore, Consumer socialization in families is a two-way process, that is, the kids also acts as a medium to socialize the parents by influencing the family purchase decisions.

Children sometimes either purchase a product themselves or select the product before it is purchased by the parents. For other products, such as ones which are used by the entire family unit, they may influence purchases made by the parents. There are some products where children wield direct influence or pester power by overtly specifying their preferences and voicing them aloud. For other products, parents' buying patterns are affected by prior knowledge of the tastes and preferences of their children. This 'passive dictation' of choice is prevalent for a wide variety of daily consumed product items as well as products for household consumption. Also, decision making in households is seen to change with the mere presence of children. It is also observed that children are socialized by their parents to act as rational consumers. After years of direct or indirect observation of parental behaviour in the marketplace, they gradually acquire relevant consumer skills from their parents.

The amount of influence exerted by children varies by product category and stage of the decision making process. For certain products they are instrumental in initiating a purchase, while for others, they make the final selections themselves. Family, peers and media are key socializing agents for children wherein familyspecific characteristics such as parental style, family's Sex Role Orientation (SRO), and patterns of communication play key roles. The Indian families have become more modern in SRO, such that the decision making has become more egalitarian (Chadha, 1995; Dhobal, 1999). Compared to this, the West is experiencing an increase in the number of single parent or female-headed households (Ahuja and Stinson, 1993; Mangleburg et al., 1999). Such a shift in family composition and structure has a bearing on the strength in the role that children are expected to play as buyers in the family.

\section{Review of literature:}

Pandey \& Singh, (2010), has analyzed the Response to advertisement, General Media habits of the Consumers, factors of maximum impact on purchase decision, the relationship between watching TV and likelihood of advertisement. Sample has been drawn from a metro city of U P that is Meerut, Respondents from only middle class families were selected, the sample was 125 coming from different occupations and education levels, income and age groups. The findings shows that there is significant relationship between watching T.V and liking of advertisement seen on the T.V., About $92 \%$ respondents agreed that they watch TV one to two hours every day. Jam, Akhtar \& khan (2010), has analyzed the Impact of marketing activities (specially adverting) on children is very important and sensitive issue for the society and marketers. They have explored with sample from 7 different schools 330 children and 107 parents to come up with practical insight of advertising influence on children memory and behaviour in Pakistani context. Their results showed interesting 
findings that ads do not impact negatively to children memory and behaviour. Priya, Baisya \& Sharma, (2009), the paper analyzed the impact of children's attitudes towards television advertisements on their resultant buying behaviour. The research has been based on exploratory and descriptive research design. The demand for the advertised products is heavily influenced by the children's attitude towards advertisements. Guneri, et al. (2009), examine the influence of children on family purchasing decision in Turkey, and author find that the children's influence on family decision-making in turkey is limited to products of direct use to children. Children are more influential on need recognition, where to buy, when to buy and which to buy sub-decisions. On other hand, the parents perceive children to have very little influence in family decision making, Fan \& Li, (2009), The purpose of this paper was to report an empirical study on children's buying behaviour in China, with a special focus on their information sources. Primary data were collected from a sample of 155 children aged ten-13 using questionnaire survey. Various statistical methods such as Pearson correlation and tests were employed to analyze the data. Chinese children regard television commercials as an important information source for new products. However, they place greater level of trust in interpersonal information sources, especially in their parents who are perceived as the most credible information source with respect to their learning about new food products. Agrawal, Tripathi \& Aditya, (2008), has analyzed the impact of television advertising on children's food preference with special reference to Delhi NCR collected data from 300 respondents in the age group of 6-16 years, Convenience based sampling was adopted and the major findings were that in India, TV ads are still the most popular media to reach kids but online ads have also created buzz, at least it come out that TV ads have positive influence on the food preference of kids in Indian prospective. Panwar \& Agnihotri, (2006), This study was designed to extend knowledge of cognitive processing of advertising messages by urban children in India. Data were collected from 250 children aged between 7 and 12years. It was found that children's ability to decode and process advertising messages and to understand their intents is influenced not only by their cognitive abilities at different age strata but also by their social and personal environments. Social norms related to acceptability and appropriateness of gender behaviour also influence the processing of ad messages by the children of both sexes. Other elements like likeability of the model, character or endorser, story line, slogan and the music will create liking or disliking for a particular advertisement and hence decoding of its message. Shoham \& Dalakas, (2006), The paper examine the influence tactics used by adolescent children and parental yielding to these tactics outside North America. The findings indicate that Israeli adolescents use rational tactics more often than emotional tactics for both products. Parental yielding follows the same pattern - it is highest for rational tactics and lowest for emotional tactics for both products. Research limitations/implications some ways to improve on this kind of research in the future are using a non-convenience sample with more balanced gender composition of adolescents and collecting data from multiple countries. Grant \& Stephen, (2005), has examined the key communicating factors which influence 12-13 year old girls in their purchasing decisions for fashion clothing. A series of four, structured focus group interviews, consisting of six girls, with questions developed after analyzing the available literature. A qualitative method of data analysis was conducted based around five related themes and the "reflective stage", 11-16 years. The findings show the key decision factors when buying are parental and peer group approval, and the purchasing of fashion items is strongly influenced by brand name and its associations. The findings revealed the respondents were prepared to pay a premium for branded clothing, placing a high emphasis on the product being deemed cool. Darian., (1998), This research has analyzed the in-store behavior of children and their parents while shopping for children's clothing. Data were collected by unobtrusively observing and recording the behavior of parents and children in retail stores. Results indicate that a purchase was more likely where both parties were highly involved in the search, the interaction was collaborative, the parent had positive evaluations of quality, price, practicality and style, the child had positive evaluations of price, style and color, and the salesperson addressed the needs of both the parent and the child. It is recommended that retailers' strategies for merchandise selection, sales force training and in-store promotions, address the needs of both parent and child.

\section{Objectives of Study:}

1). To study the role of kids in purchasing decision in family.

2). To study the factors which influence children's decision in selecting a product.

3). To study the influence of kids in purchasing decision by product category.

\section{Research Methodology:}

In this study DESCRIPTIVE RESEARCH has been followed and data has been collected from primary as well as secondary resource. The target population is parents having at least 1 child within the age group of minimum 7 years and maximum 14 years in Jalandhar city and sample size is 150 respondents and probability sampling technique with Convenience sampling has been used. Further SPSS and Microsoft office excel have been used for data analysis. 
Hypothesis:

Null Hypothesis: There is no impact of child involvement in purchase decision of products in family.

Alternative Hypothesis: There is impact of child involvement in purchase decision of products in family.

\section{Objective 1:}

Chi-Square Test

Frequencies

Age of child
\begin{tabular}{|l|l|l|l|}
\hline & Observed N & Expected N & Residual \\
\hline $7-8$ years & 33 & 21.4 & 11.6 \\
$8-9$ years & 15 & 21.4 & -6.4 \\
$9-10$ years & 14 & 21.4 & -7.4 \\
$10-11$ years & 19 & 21.4 & -2.4 \\
$11-12$ years & 16 & 21.4 & -5.4 \\
$12-13$ years & 8 & 21.4 & -13.4 \\
$13-14$ years & 45 & 21.4 & 23.6 \\
Total & 150 & & \\
\hline
\end{tabular}

Is your child involved in purchase decision of products in the family?

\begin{tabular}{|l|l|l|l|}
\hline & Observed N & Expected N & Residual \\
\hline Yes & 144 & 75.0 & 69.0 \\
No & 6 & 75.0 & -69.0 \\
Total & 150 & & \\
\hline
\end{tabular}

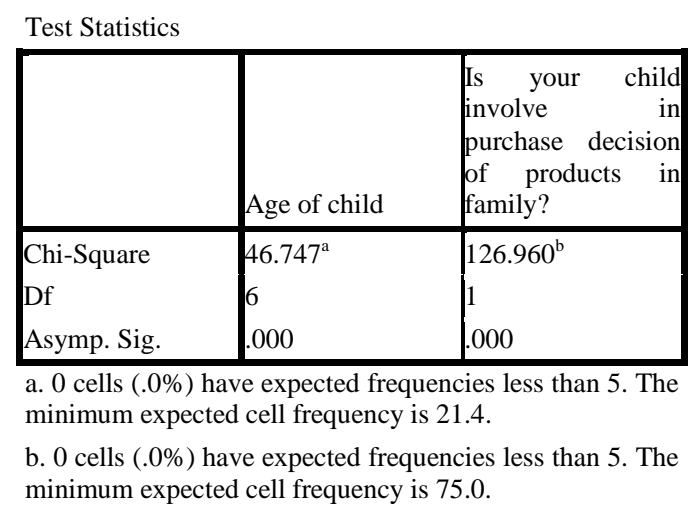

Analysis: Chi- Square test is used to find out the result of our first objective.chi--square test revealed the significant association between two variable here two variables are the age of child and their involvement in purchasing decision of product in family. The Chi square test is carried out at $90 \%$ confidence level (Equivalent to $100-90$ divided by 100 or 0.10 significance level. From the Chi square test output table we see that a significance level of .000 has been achieved and as we know that in a chi square test, for a $90 \%$ confidence level, if the significance level is greater than or equal to 0.1 , it signifies that there is no association between two variable and if significance level is less than 0.1 , then it signifies that there is a significant relationship between the selected variable. From the output tables, the chi square test read a significance level of .000 at $90 \%$ confidence level in 0.1 , that is ,(1-0.9), so the above result shows that at .000 (which is less than 0.1 ), there is a significant relationship between the two variables. Here 144 respondents out of 150 respondents said that their child is involved in purchase decision of products in family and 6 respondents said that their child is not involved in purchase decision of products in family. Here we can say that there is involvement of child in purchasing decision of product in family and there is significance relationship between age of child and involvement of child in purchasing decision. So our null hypothesis rejected and we can say that there is high involvement of child in purchasing decision of products in family and 13-14 years old child has the highest role in purchasing decision. 


\section{Objective 2:}

Crosstabs

\begin{tabular}{|c|c|c|c|c|c|c|}
\hline & \multicolumn{6}{|l|}{ Cases } \\
\hline & \multirow{2}{*}{\begin{tabular}{|l} 
Valid \\
$\mathrm{N}$
\end{tabular}} & \multirow{2}{*}{\begin{tabular}{|l} 
Missing \\
Percent
\end{tabular}} & \multicolumn{4}{|c|}{ Total } \\
\hline & & & $\mathrm{N}$ & Percent & $\mathrm{N}$ & Percent \\
\hline $\begin{array}{l}\text { Is your child } \\
\text { involve } \\
\text { purchase decision } \\
\text { of products in } \\
\text { family? } * \text { In what } \\
\text { a type of product } \\
\text { category does } \\
\text { your } \\
\text { influenced child } \\
\text { decision the } \\
\text { purchasing? }\end{array}$ & 144 & $96.0 \%$ & 6 & $4.0 \%$ & 150 & $100.0 \%$ \\
\hline
\end{tabular}

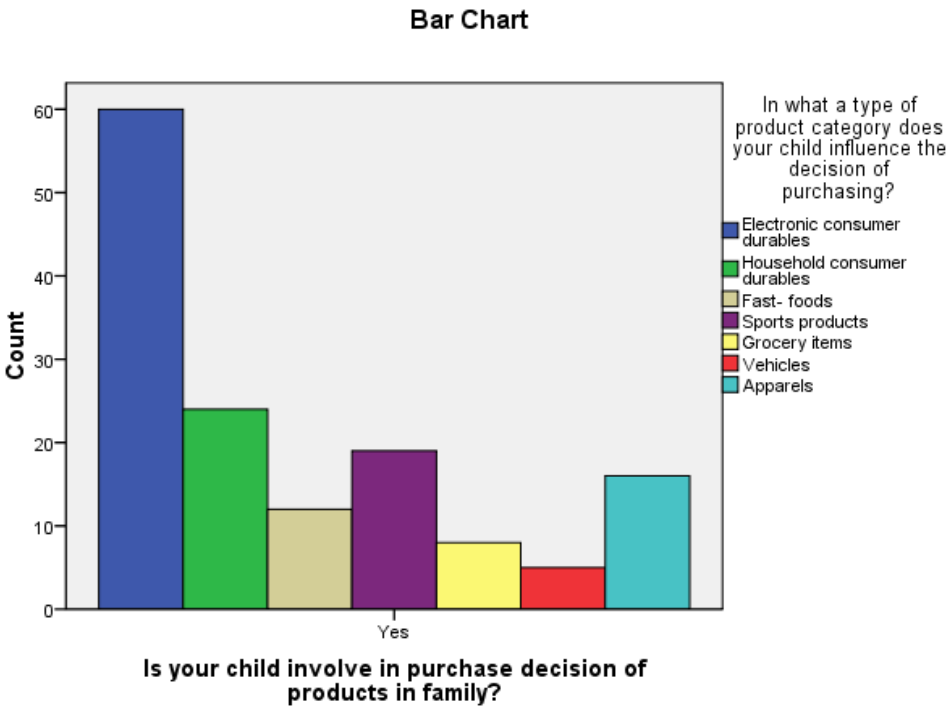

Analysis: With the help of cross tab we are able to find the influence of kids in purchasing decision by product category. With the help of bar chart we can easily say that influence of kids is highest in electronic consumer durable i.e. $60 \%$ and lowest is in vehicles i.e. around 5\%. The children are getting more information through TV advertisement regarding the product and they are well aware about the product and this thing is increasing their influence on purchasing decision.

\section{Objective 3:}

Descriptives

Descriptive Statistics
\begin{tabular}{|l|l|l|l|l|}
\hline & Minimum & Maximum & Mean & Std. Deviation \\
\hline $\begin{array}{l}\text { Advertisement } \\
\text { enhance } \\
\text { knowledge of } \\
\text { children regarding } \\
\text { the products }\end{array}$ & 144 & 5 & & \\
$\begin{array}{l}\text { Any specific toy or } \\
\text { gift attached with } \\
\text { the product } \\
\text { influence the child } \\
\text { to purchase the } \\
\text { product }\end{array}$ & 144 & 5 & .603 & .805 \\
\hline
\end{tabular}




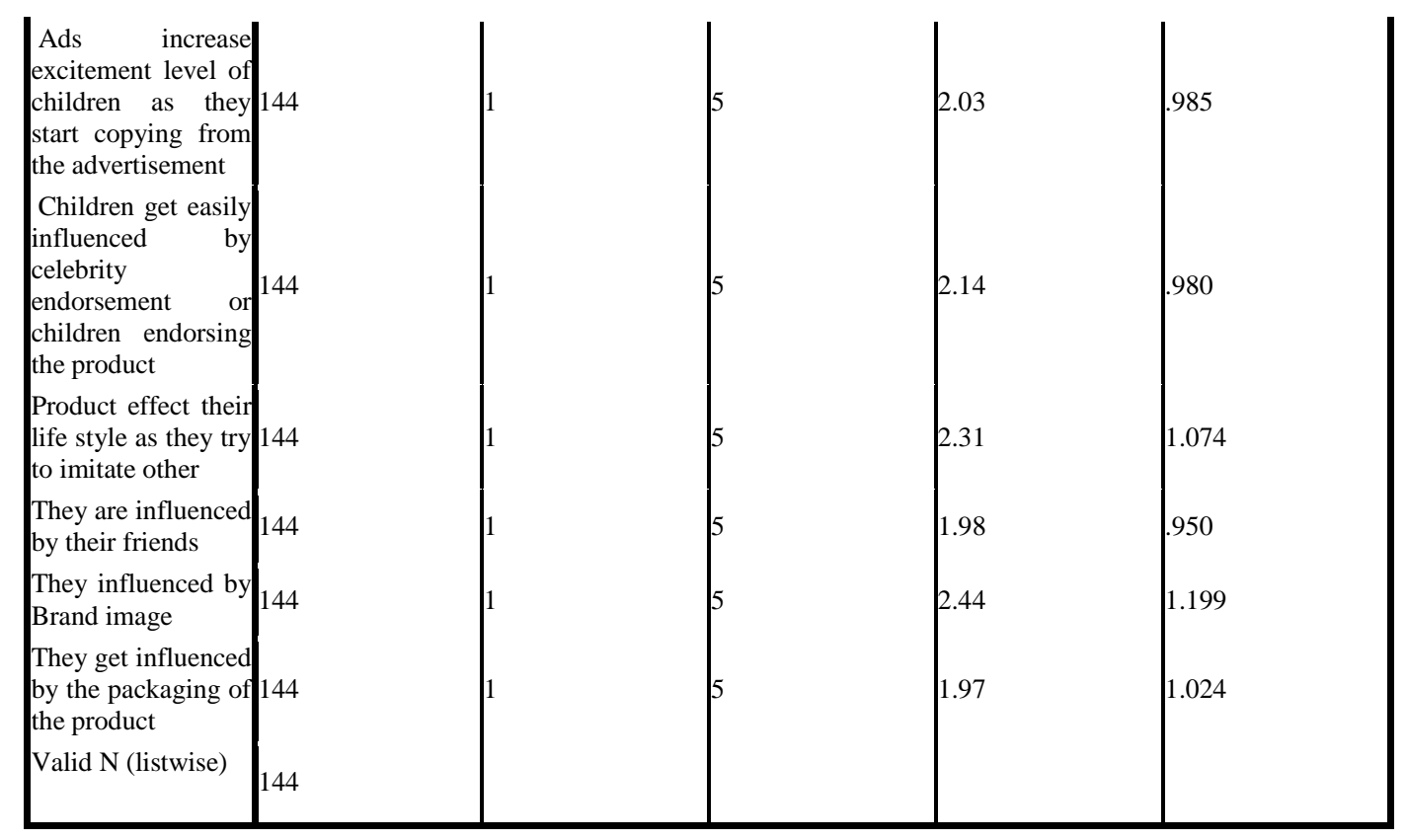

Analysis: Here if we see the table or mean value we can easily find out the factors which influence children's decision in selecting a product. The factors having least mean value are the most important factors that have their impact on children's decision in selecting a product. The descriptive table is showing all the factors and their mean value and important factor are : advertisement enhance the knowledge of children regarding the products, any specific toy or gift attached with the product influence the child to purchase the product, they are influenced by their friends and they get influenced by the packaging of the product.

\section{Findings:}

The findings show that there is an important role of child in purchasing decision of product in family \& 13-14 years old child has the highest role in purchasing decision because chi--square test revealed the significant association between two variable here two variables are the age of child and their involvement in purchasing decision of product in family. And if we talk about influence of kids in purchasing decision by product category so by using the cross tab method it is found that kids have highest influence in electronic consumer durable i.e. $60 \%$ and lowest is in vehicles i.e. around $5 \%$. By using descriptive analysis technique and Non parametric sample K S test we found the factors which influence decision of children in selecting a products, and four major factors that came out are advertisement enhance the knowledge of children regarding the products, any specific toy or gift attached with the product influence the child to purchase the product, they are influenced by their friends and they get influenced by the packaging of the product

\section{Conclusion:}

We started with the aim to find out that is there any Influence of kids on purchasing decisions of products in family or not and our findings provided astonishing insights for future researchers and marketing managers. We ended up with the findings that there is an important role of kids in purchasing decision of product in family, and they influence the purchasing decision. There are some factors which impact on the decision of children while selecting any products and most important factor that came out is the advisement. So we can conclude that advertisement have lot of impact on the children because it is one of the most important factor which impact the decision of children while selecting any products as well as it is one of the powerful media through which children is getting more information regarding products and they usually consider TV advertisement as an informative source. What we believe this study has a great importance for marketers involved in positioning and advertisement strategies and will definitely add value in marketing literature regarding impact of marketing practices on society especially on children because now days children are taking purchase decision rather than parents.

\section{Recommendation:}

So after getting the finding of our study we can recommend the marketer that they should pay attention towards the children because in these days the role of kids are increasing and parents also is giving priority to their decision. And in nuclear family where the husband and wife both are working, sometimes do not find time for shopping so they give this responsibility to their children. In that case the role of kids automatically goes 
increase. Company should choose TV for their advertisement if the message reach to a right person than it will give benefit to the company. The marketer should also pay attention towards the packaging of products because children are easily influenced by packaging of products.

\section{Bibliography:-}

[1]. Agrawal, N., Tripathi, P. \& Aditya, (2008), "senior lecturer of management", Department of Management Studies, Delhi School of Professional studies \& research Delhi, A study of the impact of Television Advertising on Children's Food Preference. Indian journal of marketing june, 2008.

[2]. Darian,C. Jean, (1998), Parent-child decision making in children's clothing stores, International Journal of Retail \& Distribution Management ,Volume 26 Number 11 · 1998 · 421-428.

[3]. Fan ,Y. \& Li, Yixuan. (2009), Children's buying behaviour in China A study of their information sources ,Marketing Intelligence \& Planning Vol. 28 No. 2, 2010 pp. 170-187

[4]. Grant, J. \& Stephen, R, (2005), Buying behaviour of "tweenage" girls and key societal communicating factors influencing their purchasing of fashion clothing. Journal of Fashion Marketing and Management Vol. 9 No. 4, 2005 pp. 450-467

[5]. Jam, A., Akhtar, S. \& Tahir, H, (2010), Impact of Advertisement on Children Behavior: Evidence from Pakistan European Journal of Social Sciences -Volume 12, Number 4 (2010)

[6]. Mittal, M, (2008), "lecturer" of Daly College of business school in Indore: Television viewing behaviour among India kids. Indian journal of marketing July, 2008 Dally college campus Indore (MP)-452001.

[7]. Panwar, J.S. \& Agnihotri, M,(2006), Advertising message processing amongst urban children An Indian experience — with special reference to TV advertising, Asia Pacific Journal of Marketing and Logistics, Emerald Group Publishing Limited,vol (18), issue 4, pg no 303-327.

[8]. Pankaj, P., Baisya, R. \& Sharma, S,(2009), Television advertisements and children's buying behaviour, Marketing Intelligence \& Planning Vol. 28 No. 2, 2010 pp. 151-169.

[9]. Pandey, A. \& Singh, A.,(2010), "Passive Dictators" of the family and Consumer Behaviour: A Case of malted food, International Trade \& Academic Research Conference (ITARC) - London 2010

[10]. Shoham, A.\& Dalakas , V.,(2006), How our adolescent children influence us as parents to yield to their purchase requests, Journal of Consumer Marketing 23/6 (2006) 344-350. 